\title{
Chapter 4 \\ The Choice of Ignorance: The Debate on Ethnic and Racial Statistics in France
}

\author{
Patrick Simon
}

\subsection{Introduction}

A researcher or a journalist trying to compare the situation of ethnic and racial minorities in the United States and in France immediately confronts a crippling obstacle. The concept of 'ethnic and racial minority' as such is not used in France. This is not simply a matter of vocabulary -something the French typically like to argue about; the problem rather lies in the very incomparability of populations that one is talking about. Many of the categories that do exist in political discourse and public debate can of course be found in statistics. But there are no data describing the situation of minorities in France that could be compared with those produced in the United States. This state of affairs in French statistics - gathering has been the subject of major criticism for some 20 years now; it has gotten to the point that it has triggered a controversy of rare violence between those that would like to see statistics take into account the diversity of the population and those who denounce the danger that such statistics might pose of ethnicizing or racializing society. The media focus on the contentiousness of this debate has been such as to sometimes lose sight of the very existence of discrimination and the flaws of the Republican model that are at the root of the controversy in the first place.

For more than a century and a half, the census has been recording the nationality and the country of birth of individuals, variables that have been used to distinguish foreigners from Frenchmen (citizens) and immigrants from natives. The statistics have served the special institutional purposes of managing immigration. They were

This chapter is an authorized reproduction by the publisher of an article published in French Politics, Culture \& Society, 26-1, p.7-31, 2008

P. Simon $(\bowtie)$

International Migration and Minorities Unit, Institut National d'Etudes Démographiques, 133 Boulevard Davout, 75020 Paris, France

e-mail: simon@ined.fr 
designed to perform a model of integration according to which immigrants would gradually lose their cultural and linguistic distinctiveness as they progressed on the path to citizenship. There was no need, therefore, to distinguish among French citizens on the basis of their origins: a political credo was believed to be tantamount to a sociological truth. Hence the descendants of immigrants have remained invisible to quantitative research. The idea of a hyphenated Frenchman (as in 'FrenchAlgerian,' for instance) acquired no political or social legitimacy (Simon 2005b). With the passage of time it became possible to claim that 'statistical identities,' and their colour-blindness or 'ethnicity-blindness', served to erase the heritage of immigration and reinforce assimilation into the nation.

Such invisibility therefore occupies a central position in the French political and legal framework, since it is supposed to ensure equality of all before the law and, consequently, in social life. Equality through invisibility - if we were to summarize the Republican strategy into a slogan - requires that ethnic and racial divisions not be represented. The credo of indifference to differences - the French colour-blind approach - leads to promoting what I would call the choice of ignorance by removing any reference to ethnic or racial origin from policies or laws - in compliance with the Constitution ${ }^{1}$ - as well as from statistics. Nevertheless, such a strategy reaches its limits with the growing spread of the categories of 'race' and ethnicity in public debates, political addresses, representations conveyed by the media and in social reports. The omnipresence of references to ethnicity and race reminds us that while France is officially a society without 'race,' racism and racial discriminations are as widespread as anywhere else. No one would contest the fact that the absence of the official use of ethnic or racial categories fails to curb the spread of prejudice and stereotypes.

The virulence of such prejudice and its translation into countless instances of discrimination, insult or humiliation based on ethnic or racial origin have for a long time been trivialized, ignored or straightforwardly denied. The main result of the social and statistical invisibility of 'race' and ethnicity may well have been to conceal the extent of discrimination. Be that as it may, since around the year 2000 discrimination has become a major political issue, and all the more so after the riots of November 2005 made the crisis of the French integration model obvious to everyone. Contributing too to this growing awareness have been the struggles, which have come to saturate the political arena, over recognizing the memory of slavery and the weight of the colonial past. In a return of the repressed of unprecedented proportions, controversies over the nature and extent of the colonial legacy ${ }^{2}$ and the appearance on the public scene of organizations - such as the Indigènes de la République [Indigenous People of the Republic], a name repeating the label given

\footnotetext{
${ }^{1}$ Article 1 of the Constitution of 1958 thus stipulates that 'France is an indivisible, secular, democratic and social Republic. It ensures equality before the law of all citizens regardless of origin, race or religion.' The question whether, with this phrase, the Constitution prohibits creating statistics referring to origin is not cut-and-dried. See the discussion later in this article on the recent decision by the Constitutional Council about the use of 'ethnic statistics.'
}

2 'Qui a peur du post-colonial?' Mouvements 51 (September 2007). 
to the colonized people in the French colonial empire or the CRAN (Conseil Représentatif des Associations Noires [Representative Council of Black Associations]) - speaking on behalf of 'racial' or racialized minorities, have come to challenge the strategy of ignoring differentiation and the colour-blind character of the Republic itself.

In this context, the issue of statistics has emerged to crystallize conflict. Hence, the unusual passion that takes hold of researchers, political leaders, antiracist associations, the media and, now, heads of companies when they bring up the question of 'ethnic statistics.' Initially a confidential topic confined to the circles of demographers and statisticians, the debate over what type of statistics to use to analyze discrimination has rapidly moved into the public sphere where it transformed into a violent controversy. The 'controversy of the demographers' began in 1998-1999 in what turned out to be only a first phase in a cycle of emotionally charged confrontations (Stavo-Debauge 2003; Spire and Merllié 1999). In the short term, the status quo was preserved. References to the Jewish files from the Vichy period and invocations of risks of various kinds of persecution seemed to disqualify the very idea of a revised approach. But the debate recently started up again with the creation of new initiatives for the fight against discrimination. The needs have become more pressing and a pragmatic approach to the issue seems to be replacing the ideological debates. Methods that provide an alternative to the creation of ethnic categories are being proposed: audit studies (known as 'testing' in French), the use of proxies, small sample surveys, etc. This article will address more specifically (1) the categories currently in use and their limitations; (2) the arguments exchanged and the justifications mobilized to support or reject 'ethnic statistics'; and (3) the alternative methods used and their limitations. As one of the protagonists involved in this debate, I cannot claim to be absolutely impartial in the presentation of the different arguments: some of them to me seem more convincing than others. I will try, however, to avoid caricature and to offer a fair rendering of this difference of opinions on what may be the main challenge all multicultural democracies are facing today.

\subsection{The Categories of Public Statistics}

Rejected as scientific and legal concepts, 'race' and ethnicity were never codified in France as categories in official statistics, save for just two exceptions related to special legal definitions: colonial statistics (which referred to the indigenous status of colonial subjects), and the 'racial' registration of Jewish people by the Vichy regime, inspired by the classification used by the Nazis. The racial category of 'Jewish' was removed from the official texts in 1944 and gradually disappeared from statistics. ${ }^{3}$

\footnotetext{
${ }^{3} \mathrm{~A}$ controversial debate broke out in the 1980 s when data going back to the war were found in the police and gendarmerie files. It all started after Serge Klarsfeld discovered a file in the archives of the minister of war veterans that looked like it could have been the 'Tulard File,' named after the Prefect of Seine in the 1940s who had coordinated the census of the Jewish people in the department.
} 
Conversely, colonial categories have lasted longer in the census carried out in Metropolitan France. To understand current debates, it is useful to take a brief look at the history of the categories 'French by acquisition' [Français par acquisition] and 'French Muslims' [Français musulmans].

From 1891 to 1999, the categories produced and used by official statistics were remarkably stable: they were limited to three categories of citizenship status 'French,' 'French by acquisition,' and 'foreigners' (Simon 1998). Some major variations were nevertheless noted; they were related to the nomenclatures used and the tabulations published in the census volumes. The categories selected by public statistics to describe immigrant populations seemed to stay within the framework of legal nationality. Nevertheless, by identifying immigrants who were 'naturalized,' they reflected by way of comparison an ambiguous notion of citizenship. Whereas by law there is practically no difference among French citizens based on the mode of acquisition of their nationality, the method by which it was acquired has been recorded since 1871 and was used in a number of detailed works between 1926 and 1946. The desire to learn about and to monitor the naturalization process, which was devised as the touchstone of the French assimilation model, led to creating and applying the category of 'French by acquisition' as an ordinary component of the population. The importance given to the 'French by acquisition' shows above all that statistics are not simply a reflection of self-evident administrative categories but are constructed in response to issues of public policy. An understanding of the reasons why people came to be registered as 'French by acquisition' thus reminds us that the objective has been, in the words of the INSEE, 'to study the assimilation of foreigners within the French population' and 'to analyze and compare the demographic and social characteristics of the various components of the population as a whole. ${ }^{4}$

The new classification of the colonial subjects of the French empire, who inherited a system in which nationality and citizenship not always coincided, also shows all the ambiguities of the 'colonial Republic' (Bancel et al. 2003). Indeed, the situation of 'indigenous' residents of the French colonial empire was always the subject of special codification in the territories under French administration. A special classification was adopted in Algeria whereby, despite extending French citizenship to all the inhabitants through the Organic Law of 1947, the distinction by status (civil or personal, which was defined on a mix of racial and religious criteria) was

\footnotetext{
The file turned out not to be that one. On this 'Jewish File' issue see Joinet L. (1991) 'Affaire dite du 'Fichier des Juifs," in CDJC Le statut des Juifs de Vichy, Paris, CDJC and (Rémond et al. 1996).

${ }^{4}$ The introduction to the 1946 census volume entitled 'Population of Foreign Origin: Naturalized Persons and Foreigners' provides the following argument: 'The questions relative to nationality that are raised in the general census must make it possible to answer three concerns: to know the distribution of the population in France among French people and foreigners, to study the assimilation of foreigners into the French population, to analyze and compare the demographic and social characteristics of the various components of the population as a whole. [...] Thus, it would be desirable to study in full the issue of the assimilation of foreigners, in order to be able to classify people based on their situation with respect to the legislation on the acquisition of French nationality.' (INSEE 1953: 305).
} 
preserved (in Article 3). The category of 'French Muslims' was thus born from the juxtaposition of the criterion of citizenship and the personal status of Muslim (Kateb 2001). Yet, while the census applied in Algeria, a French department, used a nomenclature including the various statuses, this was obviously not the case in metropoli$\tan$ France, where there had been no mention of personal status in the standard census form. This then compelled the census services to come up with an original encoding rule which, to my knowledge, has never had any equivalent. To restore the distinction by personal status, 'people born in Algeria who also have an Arabic or Berber sounding first and last name' were classified as 'Muslims native of Algeria' and those with a 'Christian or Jewish first name' as 'French-born natives of Algeria. ${ }^{5}$ The classification of names was based on a list provided by the Statistics of Algeria.

The same principle was applied in 1962, when Algeria had just acceded to independence. And in fact, how was one to recreate a division by nationality that did not exist in reality when filling out a questionnaire? While it would have been logical to group natives of Algeria by reference to their nationality (French or Algerian), it was decided at the time to preserve the inherited distinction by personal status. Once again, this was done based on people's first and last name. As a result, the categories describing migrants from Algeria grew in numbers: French-born repatriates, French Muslims who elected to preserve their French nationality, French Muslims who had become Algerian. And indeed, the 1968 census did shed some light on things insofar as the tables presenting the distribution of natives of Algeria were now based on their current nationality. One table was nevertheless still used exclusively for natives of Algeria other than repatriates (of metropolitan French ancestry, according to the classification used), which placed together the 85,520 'French Muslim natives of Algeria' and the 471,020 Algerians. Finally, a classification as 'natives of Algeria' supplemented the category of 'Algerian repatriates,' which were defined by excluding Algerian nationals and 'French Muslims.'

Whereas nomenclatures contribute to establishing an accepted division of society, the information selected by an official institution and circulated through published tables serves to legitimize the categories in use. The publication of the tables on foreigners or 'naturalized persons' was quite irregular: sometimes, there were detailed monographs; sometimes, data were practically non-existent. However, generally speaking, the volume and the nature of the tables used reflected, as did the classifications used, the public officials' preoccupations with immigration. From 1926 to 1946, censuses appeared every 5 years (though with a hiatus in 1941) in which more than 350 pages of tables presented in detail the major characteristics of foreigners and naturalized persons in France as a whole and by department. These reports included extensive details on occupational activity. This particular treatment of foreigners and naturalized persons was abandoned between 1954 and 1968, a period during which the category of 'French Muslims' appeared provisionally. The census of 1968 then inaugurated a new era in the use of the 'nationality' variable.

\footnotetext{
${ }^{5}$ Excerpt from the encoding instructions, Annex 2, General census of the population of 1962, INSEE. It is not known what decisions were made when people had an Arabic or Berber first name, but a different sounding last name. Perhaps there was never such a case.
} 
Once the shock of the decolonization was more or less absorbed, there was a revival of interest in foreigners, whose numbers had kept on growing since the beginning of the $1960 \mathrm{~s}$ - hence the special attention given to them in the census, as well as to Algerian repatriates and to the various groups of population identified on the basis of their place of birth. But the main rupture came with the introduction of nationality in the construction of tables on households and housing. At first timid (8 tables in 1968), this focus became systematic and routine after 1975. From then on, nationality became one of the major category variables, alongside sex, age or sociooccupational category. Its widespread use as a legitimate descriptor and signifier of the individual or the household thus announced and accompanied the articulation of immigration as a public issue. The censuses of 1982 and 1990 continued along this path by giving an important place to foreigners and to French people by acquisition, distinguishing them on the basis of previous nationality and place of birth. Finally, the category 'immigrant' (with a meaning close to 'foreign born') appeared in the census of 1999.

In fact, the primacy of the division by nationality in statistics extended from the census to almost all quantitative surveys and administrative files. Thus, until the end of the 1980s, immigrant populations were almost always classified in the binary categories of French and foreigners; details on the main nationalities were sometimes provided. Most often, a distinction between 'EEC foreigners' and 'non-EEC foreigners' was used to present a breakdown of individuals, households or families, and was included as an annotation in the files. These are the categories that were used, and still are, in a good number of cases, as proxies for populations that analysts tend to grasp in a completely different manner. To summarize the state of statistics available in France today, it is easy to obtain tables on foreigners or immigrants based on the census, not so often in administrative statistics, and in several surveys 'second generations' are identified. At the same time public debates bring up immigrants and talk about 'Blacks,' 'Arabs,' 'Maghrebians,' or 'youth descendants of immigrants.' The gap between the statistical categories and the terms used in everyday discourse is huge.

And yet, in the last two decades, a certain number of changes have been introduced in a rather discrete manner. The 1990s saw the spreading of the category of 'immigrants' that is fairly close to that of foreign born as used in the United States. Validated by the Haut Conseil de l'Intégration [High Council on Integration] in its first report (HCI 1991), this category was soon systematically included in the production of statistics by the INSEE (Institut National de la Statistique et des Études Économiques [National Institute for Statistics and Economic Studies]). Then the Histoire Familiale [Family History] survey, ${ }^{6}$ teaming up with the census of 1999, included for the first time in a survey of this magnitude information on the country of birth of parents. At that point the descendants of immigrants turned into a statistical category, almost 20 years after they became part of public debate and media coverage. It seemed credible to assume that this classification would quickly become widely used. This option seemed to offer a strong tactical response to the critics

${ }^{6} 380,000$ persons surveyed. 
calling for better data to describe discrimination, and it avoided taking the further step of adopting ethno-racial classifications via self-identification. Data on parents' place of birth, however, involves limitations that I will examine in detail in the third part of this article, though such limitations, from a political point of view, may be largely offset by the possibility that this category of data could offer an exit from the cycle of endless controversy that has arisen over so-called 'ethnic statistics.'

\subsection{The Controversies on 'Ethnic Statistics'}

A year before the census of 1999, a violent controversy erupted in the French press over rumours of a plan to introduce ethnic categories in the census questionnaire. ${ }^{7}$ Amid a blaze of press articles, the controversy pitted a number of researchers, on the one hand, ready to denounce the idea as part of a drift toward racism, against a few researchers, on the other, who called for modifying the statistical system, and in particular by substituting the category of immigrant for foreigner. The controversy was fuelled by the criticism of the 'Mobilité Géographique et Insertion Sociale' [Geographic Mobility and Social Integration] survey coordinated in 1992 at the National Institute for Demographic Research (Institut National d'Etudes Démographiques or INED) by Michèle Tribalat (Tribalat 1995). The use of native language to distinguish among the various native African 'ethnic groups' or among the native 'Arabophones' and 'Berbers' of Algeria and Morocco, and finally the introduction of the concept of 'ethnic belonging' in the analysis of the survey were the object of virulent attacks (Blum 1998; Le Bras 1998). The controversy between Michèle Tribalat and Hervé Le Bras, both researchers at INED became highly personalized. The media portrayed it as a battle between a 'taboo breaker' and a promoter of a Republican rhetoric of colour blindness (Stavo-Debauge 2003). When this first controversy ended, the status quo had prevailed, and the statistical apparatus remained unchanged. The episode did, however, deepen mistrust of how the managers of administrative files and of those at the INSEE handled variables having to do with immigrants. In the years that followed, the state statistics apparatus, overwhelmed by an ethical responsibility often poorly understood, practiced an excessive degree of self-censure, applying to any classification involving these variables conditions of validity that were more stringent that those worded by the data protection authority. What resulted were greater limitations on access to information showing the nationality or the country of birth of individuals (theoretically allowed, but heavily controlled in reality). The choice of censure before the fact in order to avoid any negative usage directed toward immigrant populations continues to be the favoured strategy to this day.

\footnotetext{
${ }^{7}$ The INSEE unions had sounded the alarm and obtained media coverage. An examination of the proposed changes to the census questionnaire shows however that no request to introduce ethnic categories was ever made. The existence even of a 'plan' in this sense has not been established.
} 
When the controversy resumed in 2004, the political context had changed completely. Discrimination had found its way onto the political agenda (Fassin 2002). The issue of statistics no longer concerned only the sphere of social scientists; it had become a political issue (Simon and Stavo-Debauge 2004). The desire to make discrimination more conspicuous created more pressing needs for statistical data. References to skin colour or to 'visible minorities,' an expression borrowed from the Canadian debates, had become omnipresent. While there was a large consensus on the need to fight against discrimination, the role of statistics in policy and policymaking was the subject of contrasting views. Two petitions published within less than a month of each other advocated opposing positions. In the first one 'Engagement républicain contre les discriminations' [Republican commitment against discrimination], published in the daily Libération on February 23, 2007 the signatories defended the idea that it was possible to fight against discrimination effectively by using currently available statistics and limiting oneself to audit studies. The dangers of ethno-racial categorization were put forward to justify the use of alternative methods presumed to be operational so as to avoid the creation of 'ethnic statistics.' Sponsors of the petition sought to defend the 'Republican model,' worried as they were about the risk of sliding into inter-ethnic confrontations and drifting into affirmative action [discrimination positive] on behalf of discriminated minorities. As a reaction to this petition, a manifesto was then published in the daily Le Monde. ${ }^{8}$ The signatories - the author of these lines being one of them - did not propose adopting a predefined set of categories; rather, they called attention to the deficiencies of current statistics as a basis for pursuing an antidiscrimination policy. They argued that given the systemic discrimination that occurs in France, as in any other multicultural and post-colonial society, the use of accurate statistics was an indispensable tool and that the alternative methods proposed by opponents met neither the needs of knowledge nor those of political action.

Because the stakes in this controversy clearly have gone beyond what is customary in scientific and technical debate, the exchanges have attracted a great deal of media coverage, which in turn has made them all the more violently polemical. Concepts or principles of analysis are not the only matters involved: the opponents of 'ethnic statistics' have rather sought to intervene, in the name of science, against what they see as a political danger. Mixing ends (the fight against discriminations) and means (the racialization of statistics), they are concerned that the constitutive power of statistics might strengthen ethnic or racial boundaries. It should be underscored that the controversy has not been about the nature of the findings that studies have presented on the situation of 'immigrant populations' or their descendants in French society. Few critics have challenged the analysis of the educational or professional trajectories of these groups such as have been made in those rare studies that do make use of categories of origin. Generally speaking, most researchers who criticize the idea of 'ethnic statistics' do not do research on discrimination. Their criticism grew mainly out of an 'epistemological' point of view in the social sciences - an 'epistemology' that in fact was less concerned with the conditions of

8 'Des statistiques contre les discriminations', Le Monde, March 13, 2007. 
knowledge and the establishment of 'facts' than with a desire to flag political and moral dangers. Most of these critics have not bothered to formulate concrete proposals for alternative categories.

Even though located in different political contexts, the controversies raise somewhat similar arguments. Taken together, the principal texts written against 'ethnic statistics' show recurrent topics that could be summarized as follows:

1. The use of 'ethnic variables' for scientific purposes revives the debate on the scope of the prerogatives public statistical services should be allowed to have and on their responsibility in structuring the social field. From this perspective, one can fear that by looking into the 'origins' of individuals the bodies collecting statistical information might violate their privacy. And what about respect for the rule law? Is an inappropriate use of the records, for political or other purposes, really that inconceivable? The precedent of recording information on Jewish people during Second World War and the ethno-racial profiling practiced, even today, by police and other institutions (including public housing bodies) are evidence of the reality of that risk. Despite an extremely rigorous control of the management of electronic files by the CNIL, an authority with relatively broad powers, the possibility of abuse cannot be excluded.

2. Ethno-racial classifications contribute to an essentialization of identities, relegating individuals to origins that cannot change or be transcended. These classifications tend to substitute for other forms of identification that may be just as viable and socially relevant, if not more so, such as class or gender. Essentialization and over-determination thus make the use of these categories extremely problematic. Researchers concerned about their social responsibilities would better refrain from using racist stereotypes in their work.

3. Even when ethnic or racial categories are not referring to 'objective' definitions of origin, but are based on an identification that leaves room for the actors to play a role in defining them, there is a risk of reifying blurred, unstable entities. By tracking data, the statistical classification generates boundaries within the social body, where previously there was only a loose conglomeration of moving identities. Statistics result in rigid ethnic and racial frontiers and validate commonplace prejudices.

4. The use of 'ethnic statistics' to fight against discrimination is not justified; it is possible to reveal discrimination through ethnographic observations or special surveys instead of statistical data gathering. Audit studies and indirect methods of classification, such as the use of first names, may make it possible to obtain comparable results while avoiding the collection of 'ethnic data.'

Obviously, the set of arguments called upon to disqualify the use of the concepts of 'race' and ethnicity and their operationalization in statistical categories play upon a variety of rhetorical registers. In debates, the opponents of ethnic statistics easily shift from one register to the next, mixing what pertains to the logic of political action with what is more a matter of scientific method. One of the main rhetorical tricks, for example, consists in lumping together statistics and preferential quotas. Because the idea of 'positive discrimination' is quite unpopular in France, many 
people all too readily assume that 'ethnic statistics' would only serve to ensure the creation of quotas for 'Blacks' and 'Arabs' seeking access to universities and jobs. The principle of ensuring equality of treatment through monitoring is still not very well understood. Most arguments, then, against 'ethnic statistics' share the common feature of exploiting the fear of a slippery rope by invoking apocalyptic forecasts of what will follow.

One sees this mode of argument in the reference to the Vichy government's persecution of Jewish populations during World War II. This criminal misappropriation of statistical files is now historically well established and its significance should not be underestimated. However, a distinction should be made among the various types of statistics a government might collect. Inquiries based on anonymous samples are not censuses and should not be confused with population registers or administrative files. In a remarkable study, William Selzer (1998) has shown that while the deportations of Jewish people by the Nazis and the governments collaborating with Hitler's regime were facilitated by the use of demographic statistics, it was mostly the population registers (specifying names), not the census, that had turned out to be most useful in carrying out the Final Solution. To be sure, the Nazis themselves routinely performed administrative registration in the occupied countries, as an early step in the perpetration of mass murders. In the Second World War, moreover, even democratic countries were not immune from abusing statistical records, as was the case with the use of the census in the internment of Japanese Americans (Selzer and Anderson 2001).

Another problem with the risk-of-persecution argument is that it may be applied to a large number of 'sensitive' data that are already routinely collected for purposes of redistributing resources or correcting social ills. Most social policies involve a whole series of statistics that have to do with characteristics inducing disadvantages, and for this reason, run the risk of reinforcing stigma: single-parent families, needbased scholarship recipients, the unemployed, the disabled, and so on; the list is long. The only viable guarantee that these data will only be used for legitimate purposes is provided by the state and by the data protection authority. But should the state be trusted? The negative answer implicitly given to this broad question is precisely what determines for the most part the hostility encountered by the creation of ethnic categories. This characteristic mistrust of the state clearly distinguishes France from many other countries in the North of Europe (Great Britain, Scandinavia, the Netherlands, etc.)

The use of ethnic or racial categories for purposes of research, or even more so for targeting public policy, could create the illusion that it substitutes essentialist distinctions for socially constructed definitions of difference. In reality, however, the main currents in the field of race and ethnic studies have clearly distanced themselves from the essentialist tradition. The concepts of ethnicity or of 'race' that are dominant today in the academy are constructivist in inspiration (Brubaker 2009). The recent plea of the American Sociological Association in favour of collecting 'racial' data through the federal statistical apparatus unequivocally testifies to that conviction (ASA 2003). The ASA's statement, entitled 'The Importance of Collecting Data and Doing Social Scientific Research on Race,' argues that to 
invalidate popular beliefs in the existence of 'biological races' the social effects of the circulation of racial classifications and prejudices must be studied. In this context, abandoning racial classifications would amount to precluding the understanding of one of the fundamental forms of social stratification in the United States, and - as a consequence - failing to grasp some of the most important mechanisms that produce inequality.

It is also unconvincing to argue that a focus on ethnic and racial inequality would displace or impede efforts to address socio-economic inequality. For a long time a great many studies have sought to find ways to understand the connections between 'race,' gender, and class without getting trapped into this fallacy. The role of the researcher is not to define a hierarchy of contemporary forms of domination, but instead to consider their plurality and describe their evolving configurations. In France, by contrast, where the very notions of ethnic origin and 'race' have been discredited, it is assumed these categories should not under any circumstances be exploited, even for the positive purposes of aiding individuals. Since racial categories are produced by racial thought, the idea itself of a reappropriation giving a certain prestige to the derogatory identity by the person who suffers it (reversing of stigma) is unconceivable. This line of reasoning is probably what most radically differentiates the United States and Great Britain from France: 'race' and ethnicity are regarded as self-evident in the first two countries; they are seen as nothing but a historical creation that needs to be eradicated in the case of France. A compromise between these alternative perspectives could probably be found. One may well wonder whether the negation of minority identities that prevails in France in the name of universalism is not often simply a tactic for consolidating the position of dominant groups. At any rate, it is striking to note that through some sort of pernicious effect of the universalistic logic the fight against ethnic and racial inequality leads to a deepened mistrust of any mention of origin, as if origin had become shameful in itself, a defamatory mark that should be erased as swiftly as possible.

Contested with respect to their substance, statistics involving ethnicity or 'race' are also contested with respect to their form. Whereas the variables of nationality and country of birth reproduce civil status data and are thus relatively easy to collect, the data regarding ethnicity and 'race' - when left without an institutional definition - are by nature subjective and changing. The corresponding categories are thus potentially unstable, likely as they may be to evolve under the effect of identity claims or changes in equality policies. It is, however, precisely from these limitations that the singular value of 'ethnic and racial' categories are derived; these are categories that constitute in reality - to cut against the grain of a hackneyed argument - the paradigmatic example of a non-essentialist classification system, since subjectivity is incorporated in their very definition. In this sense, they represent a new generation of quantitative data where 'authenticity' is less important than the possibility of recasting the principle and the content of categorization as a matter for debate. Because they claim to be subjective and fragile, because they assume their inscription into a history made up of slavery, colonization, xenophobia, exploitation and domination, because they prevent an evasion of what lies buried in the structures of our formally egalitarian but highly hierarchized societies, 'ethnic and racial' 
statistics have the power of revealing historically crystallized relationships of power. The use of a self-identification method makes room for the dynamics of representation, imposition and interiorization of labels to emerge. If the self-identification of persons prevails - as is the case almost everywhere today - it will also make it possible to measure the acceptance and interiorization of current labels. More generally, this registration method based on choice opens the door to a kind of 'statistical dramaturgy', through which the conflicts and competition - between majorities and minorities and within these groups - characteristic of ethnic and racial relations in multicultural societies get reflected in the classification operations themselves.

Granted, there remains a gap between the logic of self-identification and the fundamental basis of discriminatory practices: the perception that others have of the origin of individuals (third party identification). This ascribed identification and its determinants call for a sociology of appearances and markers (patronymic, linguistic, body posture, etc.). It is difficult to reduce this complexity so as to make it fit with traditional data collection practices. But an awareness of the inherent limitations in data collecting should not lead to depriving ourselves of statistical tools built on self-identification, imperfect though those tools may be. A number of studies show that there is a relatively close convergence between the classifications established by third parties and those chosen by the individuals themselves, ${ }^{9}$ or at least a sufficient convergence to make self-identification effective for the purpose of defining populations likely to be discriminated against because of their presumed 'race' or ethnicity.

Let us close this discussion of the case against statistics by looking at the terminological pitfalls that beset the Francophone world. While the terms race, ethnic group or ethnicity could not be more commonly used in English-speaking countries, they are highly charged objects of criticism in France. ${ }^{10}$ That being the case, could we use other signifiers instead of 'ethnic' and 'racial' that would still preserve the meaning that has been attributed to them? A detour through geography, 'culture' or national origin, however, raises some delicate issues. The notion of 'culture' is scarcely more consistent (nor less controversial) than that of 'ethnicity,' since using it tends to attribute explanatory power to the most obvious 'cultural' features (notably language and religion) at the expense of more political and social dimensions of ethnicity. As for geography, which postulates the primacy of a territorial relationship and sees migration as the founding event of ethnicity, its relevance - already debatable but plausible with respect to immigrants - is more than doubtful with respect to their descendants. For them ethnicity has less to do with a continuous tie to a territory or national origin than with an individual's socialization in the family and in the educational milieu (communalization, to borrow a concept from Weber). It is a matter more of history than geography. Indeed, the debate over 'ethnic statistics' is itself best understood in light of the very special relation the Republican model has to history. The difficulty in taking into account, much less overcoming,

\footnotetext{
${ }^{9}$ For France, see (Simon and Clément 2006).

${ }^{10}$ On the registers of meaning of 'ethnic' or 'ethnic group' see (Krieg-Planque 2005.) On the choice to talk about 'racist discrimination' or 'racial discrimination,' see (De Rudder et al. 2000).
} 
colonial history as well as the way immigration has been managed by the Republic remain at the core of the controversy over statistics - at its core, but never fully acknowledged.

\subsection{The Search for Alternatives: Replacements and Placebos}

Collecting ethnic data is not only a political question, it is also a legal issue framed within the restrictions of the data protection law that was adopted in 1978 and amended in 2004. Article 8 of that law stipulates as follows:

It is prohibited to collect or process data of a personal nature that reveal, directly or indirectly, the racial or ethnic origins, the political, philosophical or religious opinions, the union membership, the health or the sexual life of persons.

This ban can be lifted under certain conditions. Therefore there is no blanket prohibition, but rather a prior check over what may be done. As a result, surveys that attempts to ask questions related to ethnicity and 'race' in their questionnaires are extremely rare.

However, this legal framework regarding the collection of data has been subjected to significant criticism by researchers and, more recently, by the companies that wish to implement monitoring with a view to fighting discrimination and promoting diversity. Faced with repeated and growing pressures, on July 9, 2005 the French Data Protection Authority (Commission Nationale Informatique et Libertés, or CNIL) ${ }^{11}$ issued its first formal recommendations on the "measurement of diversity.' In them, the authority leaves it to the legislature to decide whether 'nationwide ethno-racial nomenclature' ought to be created, while acknowledging that statistics referring to origins are legitimate in the context of the fight against discrimination. These first recommendations produced no effect and the pressures grew stronger. Calls to establish a framework for using 'diversity statistics' grew significantly and came from many different sectors of society. In turn, the French High Authority against Discrimination and for Equality (Haute Autorité de Lutte contre les Discriminations et pour l'Egalité, or HALDE) declared its opposition to any 'ethnoracial nomenclature,' arguing that it was sufficient in fighting discrimination to have data on the country of birth of individuals and their parents and to carry out audit studies. ${ }^{12}$

The hostility of the HALDE towards any 'ethnic monitoring' carried out by companies for antidiscrimination purposes led the CNIL to reconvene a task force on the issue of measuring diversity. After several months of conducting hearings of researchers, representatives of anti-racist associations and human rights advocates, members of institutions, ministers and members of Parliament - some of which

\footnotetext{
${ }^{11}$ The CNIL is an independent authority created by the Data Protection Law of 1978 (amended in 2004) to ensure its application.

${ }^{12}$ Decision 2006-31 of February 27, 2006.
} 
were held in front of the press, the CNIL issued a new report on May 16, 2007. This report contains ten recommendations that open the door to a well thought-out collection of 'ethnic and racial' data as part of carefully supervised surveys, as well as to the collection of data that might be useful in analyzing how people "experience discrimination. ${ }^{13}$ The CNIL also conveyed that it was open to introducing the country of birth and nationality of parents into the census.

To widespread surprise, these recommendations inspired the filing of an amendment on 'studies on the measurement of the diversity of origins' in a legislative bill on immigration control, which Parliament examined in September 2007. Several anti-racist associations and the socialist party criticized the amendment, either for its content or for its insertion in a bill on immigration which was acutely discriminatory in itself. The HALDE and CNIL, however, supported it. ${ }^{14}$ After having been slightly modified by the Senate, the bill was officially approved on 23 October 2007. On this occasion, the HALDE issued a press release reconfirming its opposition to the creation of official 'ethnic statistics' while at the same time accepting the possibility of using 'ethnic' categories in scientific studies. ${ }^{15}$ Yet, ultimately, the Constitutional Council accepted the claim put forward by a large number of leftwing members of the parliament that the provision in the law authorizing the collection of data on race and ethnicity was unconstitutional. That provision, whose raison d'être was paradoxically to strengthen the power of control of the data protection agency, was nullified as a result, primarily on the ground that it was a rider devoid of any connection with the object and purpose of the law into which it had been inserted (regulating immigration and redefining the conditions under which foreigners could reside in France). Yet, the Council also took it upon itself to add a statement on the unconstitutional nature of any data collection process that would rely on race or ethnic origin, described as a violation of article 1 of the 1958 Constitution. What the consequences of this decision will be is difficult to say for now.

For the time being, the political and legal constraints on 'ethnic statistics' have stimulated are sourcefulness in terms of methods and makeshift solutions. Rather than collecting data on origin by asking a direct question, such data is deduced from indirect information: last and/or first name; country of birth and nationality of the individual, a person's parents or even grandparents; native language or language spoken at home. ${ }^{16}$ Taken separately or combined, these variables enable one to build categories that, after all, are not much different from 'ethnic categories' but for

\footnotetext{
${ }^{13}$ The entire report of the CNIL, as well as a verbatim of the hearings are available at http://www. cnil.fr/index.php?id=2219.

${ }^{14}$ See the CNIL press release on its website; also see the platform published by its president Alex Turk and Anne Debet, rapporteur for the task force on the measurement of diversity (Debet and Turk 2007).

${ }^{15}$ Decision 2007-233 of 24 September 2007. See the following excerpt : 'The high authority underscores that the use of such inquiries should not result in the creation of 'ethno-racial categories' and cannot under any circumstances justify the use of official files referring to, directly or indirectly, the origins of people.'

${ }^{16}$ For an inventory of the data available and of the different approaches and problems encountered, see the publication of the Strategic Analysis Council (Centre d'Analyse Stratégique, or CAS 2006).
} 
their indirect and derivative nature. These replacements or proxies underscore, by contrast, the ambiguities of statistical invisibility: some solutions could seem even more reifying than the categorization that they claim to be avoiding. In a good number of cases, they turn out to be less reliable. It is often surprising to find that the terms 'ethnic' and 'race' have the effect of the bogeyman, but when all is said and done, no one really knows what they are about.

The main strategy applied to make up for the unavailability of ethnic categories consists in collecting information with similar or equivalent meaning. In particular, the interest in descendants of immigrants has favoured the use of questions on nationality and parent's country of birth (Simon 2003). The 1999 Histoire Familiale survey, the 1993 and $2003 \mathrm{FQP}^{17}$ surveys, the employment survey ${ }^{18}$ since 2005 and the 2006 housing survey ${ }^{19}$ make it possible to analyze the situation of the descendants of immigrants. Eurostat chose this option when it introduced such data in the questionnaire of the forthcoming 2008 European labour force survey. Yet, while the study of the 'second generation' plays a crucial role in the analysis of the integration process, it is far from clear that the category of descendants of immigrants is the most appropriate for looking into ethnic and 'racial' social relationships. Easy to collect and accommodate in the French context, the category offers a pragmatic compromise in the short term, but it is bound to become obsolete with the next generations. In the case of France, the oldest waves of immigration go back to the middle of the nineteenth century. It would be impossible to describe the situation of the descendants of Belgian, German, Polish, Armenian or Italian immigrants who came prior to 1940 based on the 'second generation' category. For the most recent waves, which are also those that are truly exposed to discrimination, the criterion of the country of birth of the parents still allows one to cover between 80 and $90 \%$ of the populations concerned (Simon and Clément 2006). Yet, within the next 10 years, the subsequent generation will reach the age of social autonomy and no longer be identifiable in statistics. The transition to recording origin by selfidentification will then be the only viable solution.

Another option involves identification based on already recorded markers. Thus, first and last names constitute basic information recorded as part of the individual's (civil) identity and can be classified into quasi-ethnic categories based on what they sound like. This seemingly simple method can be applied to any administrative file. And even though these individual data are protected by the CNIL, which theoretically limits their use for statistical purposes, this approach is at the heart of a growing number of studies on segregation or discrimination. Applied to French National Education files (Felouzis 2003; ORES 2007), to corporate files (Cédiey and Foroni 2005) or to judiciary data (Jobard and Névanen 2007), the 'patronymic method' undeniably yields results. To be sure, we have no precise measurement of the magnitude of the observational biases involved in relying on first name choices. But if we assume that in most cases first names given by parents are chosen from a

\footnotetext{
${ }^{17}$ Formation et Qualification Professionnelle, approximately 40,000 persons sampled.

${ }^{18}$ Approximately 55,000 persons were polled in 1 year.

${ }^{19}$ Approximately 30,000 persons sampled.
} 
culturally limited list, they can be considered as markers of 'cultural origin' (Felouzis 2003: 420) and can therefore be used to track and measure the segregation or discrimination of the people with the relevant names.

The decision to use the first name, last name, or a combination of the two, however, is fraught with consequences. Even though it is always possible to change one's name, either through a special procedure, or through marriage, a patronym is in fact a lot more stable than a first name (Lapierre 1995). Conversely, the latter is a wonderful sociological signifier that enables one to uncover the effect of collective norms on personal choices, in particular in the case of immigrant families faced with the contradictory processes of acculturation, on the one hand, and reproduction of marks of attachment to their culture of origin, on the other. Thus, as a marker a first name is not independent from the very social processes that it is being used to measure, namely the integration process and exposure to discrimination based on origin. The choice families make to give or not to give a culturally marked first name cannot be isolated from strategies of social mobility or invisibilization [blending in]. Studies on Hispanics in the United States come to this conclusion (Sue and Telles 2007), as does most notably one of the few quantitative studies dedicated to the first names of children of immigrants (Valetas and Bringé 2005). Based on the MGIS survey conducted in 1992, M-F. Valetas and A. Bringé show that while Algerian immigrant parents choose a 'traditional' first name in $3 / 4$ of cases, their descendants born in France, i.e., the second generation of Algerians will prefer 'international' (38\%) or 'French' (22\%) first names for their children and will gradually abandon the 'traditional' $(20 \%)$ or 'modern Maghrebian' $(20 \%)$ first names. The disappearance of 'typical' first names as well as the assimilation through name change is at the root of claims by Hispanic lobbies that led to the introduction of the Hispanic question in the United States census in 1980. Until that date, 'Hispanics' were reclassified based on their first and last names by the departments of the Census Bureau. Based on the conclusion that persons of Hispanic origin were potentially underrepresented due to mixed unions and the expansion of Anglo names in the Hispanic community, the lobbies requested and obtained the introduction of the question of Hispanic origin by self-identification (Choldin 1986).

Finally, the efficiency of the patronymic method as part of the observation of discrimination processes is far from being established. The assumption under which a first and last name constitute a significant signal on the basis of which potential discriminators direct their behaviour is in part confirmed by the audit studies that have been carried out in recent years. A good deal of discrimination, however, occurs without the perpetrators knowing the civil identity of the persons that they discriminate against. And what about individuals who are exposed to discrimination due to a 'visible' sign of their origin in interpersonal interaction but who do not have a first or last name that would denote such an origin? These types of discrimination remain undetected by a method that is based on patronymic identification. And are descendents of immigrants or people from the overseas departments [DOM] who have blurred the signal usually delivered by a 'typical' first name shielded from discriminations based on other distinctive signs? Obviously not. 
Those limitations notwithstanding, does the use of first names at least make it possible to avoid the much-dreaded 'ethnicization of statistics'? In this respect, the arguments made are not exempt of hypocrisy. In fact, and despite all the carefully selected words for the occasion, ${ }^{20}$ the construction of a category of persons 'with an Arabic first name' (or 'Maghrebian' first name) makes sense in relation to a universe of ethno-cultural reference that is constitutive of patronymic semantics. An 'Arabic' first name is a classification criterion only because it is correlated with the alleged belonging of the person with such name to a group defined as Arab. The fact that origin is attributed based on a first name does not necessarily correspond to the self-identification of the persons thus classified, as Cédiey and Foroni rightly note (2005: 9). Nor does it prevent the 'Arabic first name' from being an 'ethno-racial' characteristic based on collective stereotypes. As a matter of fact, one cannot easily escape from stereotyping. Stereotypes are at the root of discrimination and therefore they will certainly surface when one tries to monitor it.

\subsection{Antidiscrimination as a New Political Frame}

The issue of discrimination finally found its place on the political agenda at the end of the 1990s in France, after having for a decade been the subject of a growing number of research studies and publications (Fassin 2002). Compared with the scholarly output in North America or Great Britain, the interest in French social sciences was certainly very slow in coming. This situation has been all the more paradoxical because works on racism as an ideology were relatively numerous and, given how long a history France had with immigration, discrimination was hardly a new phenomenon (Amiraux and Simon 2006). But it does not suffice for the facts to exist to automatically become topics of research or intervention by state authorities.

Following the 1996 report by the Conseil d'État [Council of State] on the principle of 'equality,' the 1998 report by the High Council for Integration (Haut Conseil à l'Intégration) on the 'fight against discrimination', and Minister of Employment and Solidarity Martine Aubry's speech before the Council of Ministers on October 21, 1998 proclaim equality to be the key element in the revitalization of French integration policy, the fight against discrimination has become part of the French political agenda. Two EU directives introducing the notion of indirect discrimination

\footnotetext{
${ }^{20}$ See for instance this passage from the very interesting study on access to higher education in Nord-Pas-de-Calais based on a classification by first name: 'Attributing a certain 'ethnic origin' to students here is out of the question. The debates on this concept are sufficiently old and rich to admit that a first name is only one of many more or less reliable indicators.' (ORES 2007, p.7) In a context where 'ethnic' studies have come to be seriously stigmatized, the authors have felt compelled to apologize for their identification approach and go as far as to claim that their classification does not attribute an 'ethnicity' to students 'with Arabic or Muslim first names'. What, then, does this category based on first names stand for?
} 
into European law were adopted in June and November 2000. ${ }^{21}$ They were transposed into French law by the Law of November 16, 2001 and supplemented in January 2002 by the Law on social modernization. In 2004, the HALDE succeeded the Group to Study and Combat Discriminations (Groupe d'Étude et de Lutte contre les Discriminations, or GELD), which had been created in 2000. The list of matters covered by the HALDE is now identical to those listed in the European directive on equality in employment and therefore includes sex, religion, handicap and sexual orientation, in addition to ethnic or racial origin. Between 2000 and 2005, the public system of antidiscrimination law enforcement was thus gradually set up, but has been largely unable to effectively tackle what is more akin to a discriminatory system or order than to a succession of isolated cases.

The structural dimension of discrimination is clearly acknowledged by European law, which has sought to sanction not only direct discrimination but also those forms of indirect discrimination that are more diffuse and are captured by the more sociological concept of systemic discrimination. Indirect discrimination is defined in Article 2 of the European Directive as 'an apparently neutral provision, criterion or practice likely to entail a specific disadvantage for persons of a given race or ethnic origin compared to other persons, unless such provision, criterion or practice can be objectively justified by a legitimate objective and the means to reach such an objective are appropriate and necessary.' By now this definition ought to be a standard reference in French law, but the concept has not been fully appropriated by legal and non-legal actors. The main stumbling block for putting this legal principle to use is precisely the lack of a system of categories and of the necessary statistics (Calvès 2002). France in fact was sanctioned in June 2007 by the European Commission with a request for a 'reasoned opinion' - the second and final degree of sanction prior to notifying the European Court of Justice - for its incomplete incorporation of the concept of indirect discrimination.

Indeed, the concept of indirect discrimination itself presupposes the availability of statistical monitoring. Indirect discrimination is assessed essentially through its consequences, and those can only be grasped through statistical comparisons designed to ascertain whether a given practice has what in American legal parlance is known as a 'disparate impact.' Unjust and unfavourable treatment does not consist solely in refusing to grant goods or services on account of a person's sex or origin. The question of intent is not decisive in determining whether discrimination is involved. A set of procedures and decisions, none of which is, strictly speaking, discriminatory, could end up filtering individuals in a sufficiently regular manner (but never completely - this is what separates discriminatory systems of this type from apartheid models) based on their origin without its author even consciously trying to produce that result.

\footnotetext{
${ }^{21}$ Directive 2000/43/EC of 6/29/2000 implementing the principle of equal treatment between persons irrespective of racial or ethnic origin, known as the 'race directive'; Directive 2000/78/EC 'for the creation of general framework in favor of the equality of treatment in terms of employment and occupation.'
} 
Likewise, so-called 'positive action' measures, designed to promote equality, use statistics abundantly for diagnostic purposes, to set objectives, or to evaluate the effects of policy (Simon 2005a). Based upon complex monitoring systems, these antidiscrimination policies only rarely use quotas to establish equality. Statistics are used mainly to track impediments to advancement or access, identify their internal mechanisms and measure the progress made in overcoming them. The objective is to enforce equality of treatment, rarely to grant preferential treatment to persons considered to belong to an 'ethnic or racial' minority. The regulative ideal at play here remains the impartiality of resource allocation systems, of their selection procedures and conditions of access. Yet, in the French debate, these positive action models are routinely described as being nothing more than preferential policies based on racial or ethnic quotas, which are extremely unpopular in public opinion. Quotas are then described as the inescapable end point of the establishment of statistical monitoring, in spite of the fact that the two same things are clearly distinct. The equation 'ethnic statistics = quotas' has thus become one of the most commonplace claims in the controversy, despite all attempts to correct this fallacy and to explain what is really involved in the policies promoting affirmative action and equal opportunity. This persistent effort to caricature policies designed to fight against discrimination arises in part from ignorance, but also from a deliberate strategy to discredit them in order to justify political and scientific choices. From this point of view, the debate on 'ethnic statistics' is far from being a model of intellectual rigor.

All in all, research in the social sciences, and especially in the field of statistics, is called upon to describe society not as researchers would like it to be but as it has come to be shaped by social relationships and political and institutional forces, in order to understand its dynamics and find the tools necessary to transform it. To carry out such a program, it is important to define proper questions for research and to devise methods for tackling them. It is essential to remember, too, that 'ethnic' categories are by no means unique in their fragility and in the fuzziness of their boundaries. Such properties simply require the statistician or researcher to explore the subjective dimension of classifications, even in the case of variables that appear to be the most stable and reliable. To take just one example, some of the critiques frequently levelled at 'ethnic statistics' could easily apply to socio-occupational categories (about the variation in survey responses that fail to correspond to objective changes in status, the imposition of categories that fail to capture the diversity of personal experiences, and so on). Occupational categories have problems, too, then, but this does not mean we have to challenge their existence.

Developments in the fight against discrimination have gradually led to calling into question the 'choice of ignorance'. This is no longer only a debate among specialists. The diversity charter, ${ }^{22}$ the promotion of diversity in the public service, ${ }^{23}$ diversity in the media: the calls and recommendations to introduce visible difference in the social makeup of organizations and their hierarchies are growing in

\footnotetext{
${ }^{22}$ The Diversity charter has been signed by close to 1500 companies since 2004 .

23 'Rapport sur la diversité dans la fonction publique', Dominique Versini, December 2004.
} 
numbers. Companies that have taken the initiative to ask the CNIL about the authorized methods for collecting data 'relating to diversity' are breaking new ground. The debate is far from theoretical. Directors of human resources are asking a pragmatic question: How to measure discrimination without identifying the groups likely to have suffered it? The HALDE in turn has taken a position against the establishment of 'ethnic' statistics while at the same time being open to targeted surveys. For the time being, it remains committed to a defence of audit studies as an alternative method to statistical monitoring.

In fact, the French strategy does not conform to the guidelines issued by the international bodies. The recommendations of the CERD ${ }^{24}$ to the UN (Banton 2001), of the ECRI to the Council of Europe, ${ }^{25}$ or those of the EUMC ${ }^{26}$ in Vienna aim at promoting the collection of statistical data that show, one way or another, ethnic and racial origins. In its last repor $\mathrm{t}^{27}$ to the European Council and the European Parliament on the application of Directive 2000/43/EC, the European Commission noted the critical role statistics have played in the implementation of antidiscrimination policies and the strengthening of their ability to ensure social cohesion and to promote diversity equitably. It also underscores the persistent misunderstandings, sometimes deliberately entertained, that surround the relations between data protection and the production of statistical information on discrimination. As the report put it, 'The rarity of ethnic data in most member states can, however, hinder the proper monitoring of the application of European community legislation.'

Objections have been raised to the collection of this type of data on the grounds that they presumably violate provisions of the European Union directive on data protection. This argument, however, is not quite correct. The directive prohibits in general the treatment of sensitive data of a personal nature. Some exceptions to this rule are nevertheless allowed, notably when 'the person concerned has granted explicit consent for such treatment,' or when 'the treatment is necessary for the purpose of respecting the obligations and special rights of the person responsible for such treatment in terms of labour law.' In addition, 'subject to appropriate guarantees, member states can allow exceptions on grounds of major public interest.' Therefore, member states are responsible for deciding whether ethnic data must be collected to produce statistics with a view to fighting discrimination, provided that the guarantees established by the directive on data protection are respected..$^{28}$

On a European scale, France is not the only country to experience difficulties in becoming involved in an effective equality policy. The controversies regarding statistics are nevertheless a lot more passionate there than elsewhere because of the place occupied by immigration, colonization, and slavery in the national history. The special role of the researchers in social sciences in these controversies is also

\footnotetext{
${ }^{24}$ Comité pour l'élimination de la discrimination raciale/Committee on the Elimination of Racial Discrimination.

${ }^{25}$ European Commission against Racism and Intolerance.

${ }^{26}$ European Monitoring Center on Racism, Xenophobia and Anti-Semitism.

${ }^{27} \mathrm{COM}$ (2006) 643 of 10/30/2006.

${ }^{28} \mathrm{COM}$ (2006) 643 of $10 / 30 / 2006$.
} 
exceptional in France. For a long time, reminding researchers of their civic duties was aimed at building awareness about the dangers that were thought to be inherent in the development of 'ethnic' statistics (Noiriel 2006). The collective blindness and silence that prevailed on racial discrimination were not perceived to be a matter of collective responsibility. That being said, it is obvious today that the choice of ignorance no longer protects the populations exposed to discrimination; on the contrary, it reinforces the system that puts them at an unfair disadvantage. This is indeed the meaning of the latest interventions by sociologist Dominique Schnapper, who until very recently had embodied the ideal-typical republican position in the field of integration research. She says now that 'taking ethnic categories into account will gradually happen in France as in the democracies of northern Europe,' since it is 'impossible, politically and morally, for researchers to renounce their role in the creation of the self-awareness of a democratic society by establishing knowledge that is as objective as possible' (Schnapper 2007: 99). Assuming, however, that this French exceptionality among multicultural societies is indeed fast disappearing, the joint agenda of research and public decision on the issue of discrimination has only begun. What should 'ethno-racial' categories look like, how and where could they be collected, and according to which procedure would the categories be defined: there is a new research frontier that awaits us beyond the controversies and caricatures that have come with the 'choice of ignorance.'

Open Access This chapter is distributed under the terms of the Creative Commons Attribution Noncommercial License, which permits any noncommercial use, distribution, and reproduction in any medium, provided the original author(s) and source are credited.

\section{References}

American Sociological Association. (2003). The importance of collecting data and doing social scientific research on race. Washington, DC: American Sociological Association. http://www. asanet.org/images/press/docs/pdf/asa_race_statement.pdf.

Amiraux, V., \& Simon, P. (2006). There are no minorities here: Cultures of scholarship and public debate on immigrants and integration in France'. International Journal of Comparative Sociology, 47(3-4), 191-215.

Bancel, N., Blanchard, P., \& Vergès, F. (2003). La république coloniale. Essai sur une utopie. Paris: Albin-Michel.

Banton, M. (2001). Ethnic monitoring in international law: The work of the CERD. In A. Krizsàn (Ed.), Ethnic monitoring and data protection: The European context (pp. 62-85). Budapest: CEU-INDOK.

Blum, A. (1998). Comment décrire les immigrés - à propos de quelques recherches sur l'immigration. Population, 3, 569-587.

Brubaker, R. (2009). Ethnicity, race, and nationalism. Annual Review of Sociology, 35, 21-42.

Calvès, G. (2002). Il n'y a pas de race ici': le modèle français à l'épreuve de l'intégration européenne. Critique Internationale, 17, 173-186.

Cédiey, E., \& Foroni F. (2005). 'Un diagnostic partagé sur les discriminations liées à l'origine et au sexe. Résultat d'une recherche-action au sein du groupe Casino', ISM-Corum, mimeographed report. 
Centre d'Analyse Stratégique. (2006). Statistiques 'ethniques': éléments de cadrage', Rapports et documents (Vol. 3). Paris: La Documentation Française.

Choldin, H. (1986). Statistics and politics: The 'Hispanic issue' in the 1980 census. Demography, $23,403-418$.

Debet, A., \& Turk, A. (2007). Statistiques de la diversité: plaidoyer pour la raison, Le Monde, 10/10/2007.

De Rudder, V., Poiret, C., \& Vourc'h, F. (2000). L'inégalité raciste. L'universalité républicaine à l'épreuve. Paris: PUF.

Fassin, D. (2002). L'invention française de la discrimination. Revue Française de Science Politique, 52(4), 403-423.

Felouzis, G. (2003). La ségrégation ethnique au collège et ses conséquences. Revue Française de Sociologie, 44-3, 413-447.

Haut Conseil à l'Intégration. (1991). Pour un modèle français d'intégration, first annual report of the Haut Conseil à l'Intégration. Paris: La Documentation Française.

INSEE. (1953). Résultats statistiques du recensement général de la population effectué le 10 mars (Population présente totale, 6e partie Population d'origine étrangère: étrangers et naturalisés, Vol. 2). Paris: PUF-INSEE.

Jobard, F., \& Névanen, S. (2007). La couleur du jugement. Discriminations dans les décisions judiciaires en matière d'infractions à agents de la force publique (1965-2005). Revue Française de Sociologie, 48(2), 243-272.

Kateb, K. (2001). Européens, 'indigènes' et juifs en Algérie: 1830-1962: représentations et réalités des. Paris: INED-PUF. Travaux et documents cahier No. 145.

Krieg-Planque, A. (2005). 'Le mot "ethnie": nommer autrui. Origine et fonctionnement du terme "ethnie" dans l'univers discursif français', Cahiers de lexicologie. Revue internationale de lexicologie et lexicographie, 87, 141-161.

Lapierre, N. (1995). Changer de nom. Paris: Stock.

Le Bras, H. (1998). Le démon des origines. Démographie et extrême droite. La Tour d'Aigues: Editions de l'Aube.

Mouvements. (2007). 'Qui a peur du post-colonial?' Mouvements, No. 51, September.

Noiriel, G. (2006). Color blindness' et construction des identités dans l'espace public français'. In D. Fassin \& E. Fassin (Eds.), De la question sociale à la question raciale? Représenter la société française (pp. 158-174). Paris: La Découverte.

ORES. (2007). Porter un prénom arabe ou musulman est-il discriminant dans l'enseignement supérieur?'. Nord-Pas de Calais: ORES Population.

Rémond, R., Azéma, J.-P., \& Kaspi, A. (dir.) (1996). Le " Fichier juif », rapport de la commission présidée par René Rémond au Premier ministre. Paris: Plon.

Schnapper, D. (2007). Qu'est-ce que l'intégration ? Paris: Gallimard.

Selzer, W. (1998). Population statistics, the Holocaust, and the Nuremberg trials'. Population and Development Review, 24(3), 511-552.

Selzer, W., \& Anderson, M. (2001). The dark side of numbers: The role of population data systems in human rights abuses'. Social Research, 68(2), 481-513.

Simon, S. (1998). Nationality and origins in French statistics: Ambiguous categories'. Population, An English Selection, 11, 193-219.

Simon P. (2003). 'Les sciences sociales françaises face aux catégories ethniques et raciales', Annales de Démographie Historique, "Politique des recensements", 1,111-130.

Simon, P. (2005a). The measurement of racial discrimination: The policy use of statistics'. International Social Science Journal, 183, 9-25.

Simon, P. (2005b). 'La République face à la diversité: Comment décoloniser les imaginaires?'. In N. Blanchard, N. Bancel, \& S. Lemaire (Eds.), La fracture coloniale (p. 237). Paris: La Découverte.

Simon P. \& Clément M. (2006, July-August). "How should the diverse origins of people living in France be described?", Population \& societies, No. 425. 
Simon, P., \& Stavo-Debauge, J. (2004). Les politiques anti-discrimination et les statistiques: paramètres d'une incoherence. Sociétés Contemporaines, 53, 57-84.

Spire, A., \& Merllié, D. (1999). La question des origines dans les statistiques en France. Les enjeux d'une controverse'. Le Mouvement Social, 188, 119-130.

Stavo-Debauge, J. (2003). Prendre position contre les catégories ethniques. Le sens commun constructiviste, une manière de se figurer un danger. In P. Laborier \& D. Trom (Eds.), Historicité de l'action publique (pp. 11-45). Paris: PUF.

Sue, C., \& Telles, E. (2007). Assimilation and gender in naming. American Journal of Sociology, $112-5,1383-1415$.

Tribalat, M. (1995). Faire France: une grande enquête sur les immigrés et leurs enfants. Paris: la Découverte.

Valetas, M.-F., \& Bringé, A. (2005). The first name of the children of immigrants in France. In K. Slany (Ed.), International migration: A multidimensional analysis (pp. 289-297). Cracow: AGH University of Science and Technology Press. 